\title{
NEUROPATHIC PAIN AND DISABILITY IN PATIENTS WITH LUMBAR SPINAL STENOSIS
}

Turkish Journal of Geriatrics

DOI: 10.31086/tjgeri.2018137967

2018;21 (1):56-61

- Mehmet AĞIRMAN ${ }^{1}$

- Ayşe Serap AKGÜN²

CORRESPONDANCE

Mehmet AĞIRMAN

Istanbul Medipol University,

Faculty of Medicine, Department of Physical

Medicine and Rehabilitation

istanbul, Turkey

Phone: 4447070

e-mail: mehmetagirman@yahoo.com

Received: 14/02/2018

Accepted: 05/03/2018

1 İstanbul Medipol University,

Faculty of Medicine, Department of Physical

Medicine and Rehabilitation

Istanbul, Turkey

2 Istanbul Medipol University

Department of Radiology

Istanbul, Turkey

\section{Abstract}

Introduction: In this study, we aimed to determine the characteristics of neuropathic pain and clarify the relationships between the clinical signs, symptom characteristics and disability in patients with lumbar spinal stenosis.

Materials and Method: Seventy-nine patients diagnosed with clinical and radiological lumbar spinal stenosis were included in the study. Pain severity was assessed using a selfadministered visual analog scale $(0-10 \mathrm{~cm})$. Subjective disability was measured using the Oswestry Disability Index and Istanbul Low Back Pain Disability Index. To identify neuropathic pain, the physician-administered Douleur Neuropathique 4 questionnaire was utilized.

Results: A total of 79 patients ( 35 males, 44 females) with a mean age of $56.88 \pm 12.13$ (range, $35-89)$ years were included in the study. The average symptom duration was 24.5 months. The Douleur Neuropathique 4 score was $\geq 4$ in 41 patients (51.8\%), indicating that they had neuropathic pain. A significant correlation was observed between the Douleur Neuropathique 4 score and age $(R=0.350, p=0.002)$, body mass index $(R=0.239, p=0.034)$, and visual analog scale $(R=0.453, p<0.001)$.

Conclusion: Approximately half of all patients with lumbar spinal stenosis in our cohort had neuropathic pain. Higher age, body mass index and increased pain scores demonstrate important relationships with neuropathic pain.

Keywords: Neuralgia; Spinal Stenosis; Pain; Aged
ARAŞTIRMA

\section{LOMBER SPINAL STENOZLU HASTALARDA NÖROPATIK AĞRI VE YETI KAYBI}

\section{$\ddot{O}_{z}$}

Giriş: Bu çalışmada, lomber spinal stenoz hastalarında nöropatik ağrı karakterini belirlemeyi ve klinik semptom, bulgu ve yeti kaybı ile olan ilişkisini araştırmayı amaçladık.

Gereç ve Yöntem: Çalışmaya klinik ve radyolojik olarak lomber spinal stenoz tanısı alan yetmiş dokuz hasta alındı. Ağrı düzeyi için visüel analog skala $(0-10 \mathrm{~cm})$, fonksiyonel durum için Oswestry Dizabilite İndeksi ve İstanbul Bel Ağrısı Dizabilite Indeksi ölçüldü. Nöropatik ağrıyı belirlemek için Douleur Neuropathique 4 anketi dolduruldu.

Bulgular: Ortalama yaşı 56.88 12.13 (35-89 yaş aralığı) olan 79 hasta (35 erkek, 44 kadın) çalışmaya dahil edildi. Ortalama semptom süresi 24,5 ay idi. Hastaların $41^{\prime}$ inde (\%51.8) Douleur Neuropathique 4 skoru $\geq 4$ (nöropatik ağrı) idi. Douleur Neuropathique 4 sonucu ile yaş $(R=0.350, p=0.002)$, vücut kitle indeksi $(R=0.239, p=0.034)$ ve visüel analog skala $(R=0.453, p<$ 0.001) arasında anlamlı ilişki görüldü.

Sonuç: Çalışmamızda, hastaların yaklaşık yarısında nöropatik ağıı gözlendi. Illeri yaş, yüksek vücut kitle indeksi ve artmış ağrı skorları ile nöropatik ağrı arttığı sonucuna ulaşıldı.

Anahtar sözcükler: Nöralji; Spinal stenoz; Ağrı; Yaşlı 


\section{INTRODUCTION}

Lumbar spinal stenosis (LSS) is one of the most common conditions, which causes pain and disabilities in older people (1). This condition is commonly associated with lumbar degenerative disc disease and spondylosis so-called acquired lumbar stenosis (2). It results in the narrowing of the spinal canal, lateral nerve roots, and intervertebral neural foramina at one or more levels. Clinical signs occur because of compression of the spinal cord, nerve roots, and vascular elements of the lumbar spine (3). These symptoms include pain in the back, buttocks, and lower leg; numbness in the leg or foot, weakness in the lower extremities, and neurogenic claudication (4).

There are several classifications and types of pain, including nociceptive, chronic, radicular, and neuropathic. Understanding these can aid in diagnosis and planning appropriate treatment (5). Neuropathic pain (NeP) has been defined as pain caused by a lesion or disease of the somatosensory system. Patients usually complain of burning and electrical sensations, with pain often resulting from typically non-painful stimulation (e.g., light touch) (6).

LSS can be diagnosed based on clinical, neurological, and radiological findings. However, radiological LSS can be detected using magnetic resonance imaging (MRI) or computed tomography in asymptomatic patients. A clinical diagnosis of LSS requires both the characteristic clinical presentation and radiographic evidence of LSS (7). Neurogenic claudication and radicular pain are best described in the literature for patients with LSS $(7,8)$. However, there are few studies on $\mathrm{NeP}$ in patients with spinal stenosis $(9,10)$.

In this study, we aimed to determine the characteristics of $\mathrm{NeP}$ and clarify the relationships between the clinical signs and symptom characteristics in patients with LSS.

\section{MATERIALS AND METHOD}

\section{Participants}

One-hundred and sixteen patients with LSS symptoms were included in the study between
February 2016 and November 2017. All patients signed written informed consent forms to participate in the study, which was approved by the local ethics committee. This study was conducted in accordance with the principles of the Declaration of Helsinki.

All patients were recruited from the outpatient clinic of the Department of Physical Medicine and Rehabilitation. Clinical LSS was diagnosed based on symptoms of pain in the buttocks or thighs, pain in the lower leg induced by lumbar spine extension, numbness or tingling in the leg or foot, and neurogenic claudication. Patients diagnosed with clinical LSS were included if lumbar spine MRI showed signs of LSS. Radiological LSS was accepted as absolute if the sagittal spinal canal diameters measured $\leq 10 \mathrm{~cm}$ in at least one intervertebral disc (11). Initially, seventy nine patients with both the characteristic clinical presentation and radiographic evidence of LSS were collected. Patients were excluded if they had previously undergone spine $(n=3)$, hip, and/or lower limb-related surgery $(n=3)$; diabetes $(n=7)$; peripheral vascular disease $(n=1)$; and/or inflammatory disorders $(n=2)$. Furthermore, we also excluded those with a symptom duration of $<1$ month $(n=7)$ and those taking drugs for $\mathrm{NeP}$, such as pregabalin, gabapentin, tricyclic antidepressants, or selective serotonin-norepinephrine reuptake inhibitors $(n=14)$.

\section{Assessment of symptoms and functional disability}

All questionnaires and clinical evaluations were recorded by a blinded physician to the clinical and radiological findings. A detailed medical history was taken and physical examination was performed, and age, gender, height, weight, body mass index (BMI), and symptom duration were recorded for each patient.

Low back pain severity was assessed using a self-administered visual analog scale (VAS; range, 0-10 cm). Subjective disability was measured using the Oswestry Disability Index (ODI; range 0-100) and Istanbul Low Back Pain Disability Index (ILBPDI; range $0-90)$. ODI is a 10-item, self-administered questionnaire that is commonly used to assess 
limitations in activities of daily living because of low back pain. Disability increases as the total ODI score increases. ILBPDI focuses on activities required to function in daily life, such as transport, sitting, standing, dressing, and hygiene, and where they are done (e.g., room, kitchen, car, or street).

To identify $\mathrm{NeP}$, the physician-administered Douleur Neuropathique 4 (DN4) questionnaire was utilized. This questionnaire contains seven items related to symptoms and three related to clinical examination. Each item is scored as 1 (positive) or 0 (negative), and a total score of $\geq 4$ out of 10 suggests $\mathrm{NeP}$. The questionnaires have Turkish validity and reliability $(12,13)$.

\section{Statistical analysis}

All qualitative variables are reported as frequencies and percentages. Continuous variables are expressed as means \pm standard deviations. The correlations between DN4, ODI, ILBPDI, VAS, and other clinical signs were calculated using the Spearman's correlation coefficient. IBM SPSS for Windows, Version 21 (IBM Corp., Armonk, NY, USA) was used for all statistical analyses. $P$-values $<0.05$ were considered to be statistically significant.

\section{RESULTS}

The clinical and demographic characteristics of the participants are summarized in Table 1. A total of 79 patients ( 35 males, 44 females) with a mean age of $56.88 \pm 12.13$ (range, 35-89) years were included in the study. All patients were clinically and radiologically diagnosed with LSS. The average symptom duration was 24.5 months (Table 1).

In terms of the questionnaires, the average VAS, ODI, ILBPDI, and DN4 scores were $6.84 \pm 1.38,29.93 \pm 5.92,23.08 \pm 7.73$, and $4.07 \pm 2.26$, respectively. The DN4 score was $\geq 4$ in 41 patients (51.8\%), indicating that they had NeP. A significant correlation was observed between the DN4 score and age $(R=0.350, p=0.002), B M l(R=0.239$, $p=0.034)$, and VAS $(R=0.453, p<0.001)$. There was also a significant correlation between the ODI score and age $(R=0.438, p<0.001)$, VAS score $(R=0.420$, $p<0.001)$, and ILBPDI score $(R=0.708, p<0.001)$. Finally, there was a significant correlation between the ILBPDI score and both age $(R=0.426, p<0.001)$ and VAS score $(R=0.250, p=0.026)$. However, the symptom duration was not significantly correlated with any of the questionnaires (Table 2).

Claudication was present in $41.8 \%$ of patients. Using DN4, most patients complained of tingling (67.1\%) and numbness (51.9\%), with the least number of patients complaining of itching $13.9 \%$; Table 3). In the physical examination, hypoesthesia to touch, hypoesthesia to pinprick, and increased pain by brushing were present in $61.9 \%, 65.8 \%$, and $21.5 \%$ of the patients, respectively.

Table 1. The clinical and demographic characteristics of patients.

\begin{tabular}{lll}
\hline Characteristics & Mean \pm sd & Minimum-Maximum \\
\hline Age & $56.88 \pm 12.13$ & $33-89$ \\
Gender (M/F) & $44 / 35$ & \\
BMI & $29.91 \pm 3.54$ & $19.81-38.28$ \\
Sd (month) & $24.50 \pm 27.75$ & $1-120$ \\
VAS (0-10 cm) & $6.84 \pm 1.38$ & $4-10$ \\
ODI (0-100) & $29.93 \pm 5.92$ & $13-46$ \\
ILBPDI (0-90) & $23.08 \pm 7.73$ & $7-46$ \\
DN4 (0-10) & $4.07 \pm 2.26$ & $1-10$ \\
\hline
\end{tabular}

BMI: Body mass index; SD: Symptom duration; VAS: Visual analog scale; ODI: Oswestry Disability Index; ILBPDI: Istanbul Low Back Pain Disability Index; DN4: Douleur Neuropathique 4 
Table 2. Correlations of demographical findings, pain, subjective disability and neuropathic pain (r-values).

\begin{tabular}{|c|c|c|c|c|c|c|c|}
\hline Characteristics & Age & BMI & sd & VAS & ODI & ILBPDI & DN4 \\
\hline Age & 1 & & & & & & \\
\hline BMI & 0.037 & 1 & & & & & \\
\hline sd & 0.159 & 0.075 & 1 & & & & \\
\hline VAS & $0.322^{\star \star}$ & 0.210 & 0.094 & 1 & & & \\
\hline ODI & $0.438 * \star$ & 0.205 & 0.001 & $0.420 * \star$ & 1 & & \\
\hline ILBPDI & $0.426^{* *}$ & 0.079 & -0.042 & 0.250 & $0.708^{\star \star}$ & 1 & \\
\hline DN4 & $0.350 * \star$ & $0.239 *$ & 0.174 & $0.453^{\star *}$ & 0.221 & 0.211 & 1 \\
\hline
\end{tabular}

BMI: Body mass index; SD: Symptom duration; VAS: Visual analog scale; ODI: Oswestry Disability Index; ILBPDI: Istanbul Low Back Pain Disability Index; DN4: Douleur Neuropathique 4

*. Correlation is significant at the 0.05 level

**. Correlation is significant at the 0.01 level

Table 3. The percentage of neurogenic claudication and positive signs and symptoms assessed by DN4 questionnaire in LSS patients.

\begin{tabular}{lrr}
\hline Characteristics & Yes (\%) & No (\%) \\
\hline Claudication & 41.8 & 58.2 \\
DN4 questions & & \\
Burning & 43.0 & 57.0 \\
Painful cold & 25.3 & 74.7 \\
Electric shocks & 39.1 & 60.9 \\
Tingling & 67.1 & 32.9 \\
Pins and needles & 45.6 & 54.4 \\
Numbness & 51.9 & 48.1 \\
Itching & 13.9 & 86.1 \\
Hypoesthesia to touch & 61.9 & 38.1 \\
Hypoesthesia to prick & 65.8 & 34.2 \\
Brushing & 21.5 & 78.5 \\
\hline
\end{tabular}

\section{DISCUSSION}

In this study, we showed that most patients with LSS had NeP associated with age; BMl; and ODI, VAS, and ILBPDI scores. The prevalence of degenerative disc disease and neuropathic pain syndromes are known to increase with both aging and spinal stenosis $(14,15)$. In our study, a correlation was observed between increased age and DN4, ODI, and ILBPDI scores. These results might have resulted from increased degeneration and stenosis typically associated with increased aged. 
Lumbar spinal stenosis has heterogeneous and nonspecific signs and symptoms and may even be asymptomatic, with symptoms assumed to result from nerve compression, local vascular insufficiency, or both (1). Indeed, radiological findings do not prove that symptoms arise from nerve root compression (16). Neurogenic claudication, back and leg pain, comorbidities, and other nociceptive pain indexes are well studied in patients with LSS (16-19). It has also been reported that patients with LSS have less intense leg pain than those with lumbar disc herniation and that their symptoms are more often increased by lumbar extension and relieved by bending forward or sitting $(2,17,20)$.

The pain in LSS can be divided into two main categories: nociceptive and neuropathic. $\mathrm{NeP}$ is defined as the pain caused by a lesion or disease of the somatosensory system, and it is estimated to affect $15 \%-25 \%$ of patients with chronic pain $(8,21)$. Although $\mathrm{NeP}$ is a clinical diagnosis, there are several diagnostic criteria. In Turkey, DN4 has been the best performing screening tool with good validity and reliability (13). This tool assesses symptoms of burning, tingling, sensitivity to touch, pain caused by mild pressure, electric shock-like pain, pain to cold or heat, and numbness, which are characteristic NeP symptoms.

In our study, 41 patients (51.8\%) had NeP according to the DN4 questionnaire, and this was shown to be correlated with increased BMI. In another study of 102 patients, the painDETECT questionnaire was used to show that nociceptive, neuropathic, and unclear pain were present in $57.9 \%$, $17.6 \%$, and $24.5 \%$ of patients, respectively (9). Even if the unclear pain is combined with the NeP group, the $\mathrm{NeP}$ rate still only reached $42.1 \%$. Our high values of $\mathrm{NeP}$, may have resulted from using the DN4 questionnaire. In the above study, they showed that the group with $\mathrm{NeP}$ had a significantly poorer quality of life than the other groups. However, ODI, ILBPDI and symptom duration did not significantly correlate with DN4 questionnaire (Table 2).

In patients with LSS, pain mostly spreads to the buttock or thighs and to both lower legs, with patients also complaining of numbness and tingling (19). For patients with chronic low back pain and LSS, other researchers have also reported that buttock and leg pain were significantly associated with $\mathrm{NeP}$ $(10,22)$. Our results are consistent with these results, showing that most subjects complained of leg symptoms (e.g., tingling in $67.1 \%$ and numbness in $51.9 \%)$, including claudication (41.8\%), and that very few complained of itching (Table 3).

There are conflicting results about the association between radiological and clinical findings. In a multicenter study, no relationship was shown between the radiological severity and the presence of back or leg pain in patients with LSS (23). In another research, the opposite was shown to some extent (24). Although we believe that the radiological distinction could be ignored because of the selection of only symptomatic patients in our study, further research is needed in relation to this topic.

Except the radiological distinction there are other limitations in the present study. Although the frequency of neurogenic claudication determined in the study, the walking distance/duration was not measured. The other limitation is that the quality of life was not evaluated.

In conclusion, approximately half of all patients with LSS in our cohort had NeP. Higher age, BMls and increased VAS scores demonstrate important relationships with $\mathrm{NeP}$.

\section{Conflict of interest}

The authors have no conflict of interest to declare. 


\section{REFERENCES}

1. Backstrom KM, Whitman JM, Flynn TW. Lumbar spinal stenosis-diagnosis and management of the aging spine. Man Ther 2011;16(4):308-17. (PMID:21367646).

2. Gilbert JW, Martin JC, Wheeler GR, et al. Lumbar stenosis rates in symptomatic patients using weightbearing and recumbent magnetic resonance imaging. J Manipulative Physiol Ther 2011;34(8):55761. (PMID:21907413).

3. Ishimoto Y, Yoshimura N, Muraki S, et al. Associations between radiographic lumbar spinal stenosis and clinical symptoms in the general population: the Wakayama Spine Study. Osteoarthritis Cartilage 2013;21(6):783-8. (PMID:23473979).

4. Battié MC, Jones CA, Schopflocher DP, Hu RW. Health-related quality of life and comorbidities associated with lumbar spinal stenosis. Spine J 2012;12(3):189-95. (PMID:22193054).

5. Nalamachu S. An overview of pain management: the clinical efficacy and value of treatment. Am J Manag Care 2013;19(14):261-6. (PMID:24494608).

6. Cohen SP, Mao J. Neuropathic pain: mechanisms and their clinical implications. BMJ 2014;348:f7656. (PMID:24500412).

7. Suri P, Rainville J, Kalichman L, Katz JN. Does this older adult with lower extremity pain have the clinical syndrome of lumbar spinal stenosis? JAMA 2010;304(23):2628-36. (PMID:21156951).

8. Djurasovic M, Glassman SD, Carreon LY, Dimar JR. Contemporary management of symptomatic lumbar spinal stenosis. Orthop Clin North Am 2010;41(2):183-91. (PMID:20399357).

9. Takahashi N, Shirado O, Kobayashi K, Mashiko R, Konno S. Classifying patients with lumbar spinal stenosis using pain DETECT: a cross-sectional study. BMC Fam Pract 2016;17:90. (PMID:27443164).

10. Orita S, Yamashita T, Ohtori S, et al. Prevalence and Location of Neuropathic Pain in Lumbar Spinal Disorders: Analysis of 1804 Consecutive Patients With Primary Lower Back Pain. Spine (Phila Pa 1976) 2016;41(15):1224-31. (PMID:26967122).

11. Kalichman L, Cole R, Kim DH, et al. Spinal stenosis prevalence and association with symptoms: the Framingham Study. Spine J 2009;9(7):545-50. (PMID:19398386).

12. Duruöz MT, Özcan E, Ketenci A, Karan A. Development and validation of a functional disability index for chronic low back pain. J Back Musculoskelet Rehabil 2013;26(1):45-54. (PMID:23411648).

13. Unal-Cevik I, Sarioglu-Ay S, Evcik D. A comparison of the DN4 and LANSS questionnaires in the assessment of neuropathic pain: validity and reliability of the Turkish version of DN4. J Pain 2010;11(11):1129-35. (PMID:20418179).

14. Zeifang F, Schiltenwolf M, Abel R, Moradi B. Gait analysis does not correlate with clinical and MR imaging parameters in patients with symptomatic lumbar spinal stenosis. BMC Musculoskelet Disord 2008;9:89. (PMID:18570636).

15. Kutsal YG, Eyigör S, Dogan A, et al. Neuropathic pain in elderly: a multicenter study. Turkish Journal of Geriatrics 2016;19(1):9-18.

16. Konno S, Kikuchi S, Tanaka Y, et al. A diagnostic support tool for lumbar spinal stenosis: a selfadministered, self-reported history questionnaire. BMC Musculoskelet Disord 2007;8:102. (PMID:17967201).

17. Rainville J, Lopez E. Comparison of radicular symptoms caused by lumbar disc herniation and lumbar spinal stenosis in the elderly. Spine (Phila Pa 1976) 2013;38(15):1282-7. (PMID:23462576).

18. Kim YU, Kong YG, Lee J, et al. Clinical symptoms of lumbar spinal stenosis associated with morphological parameters on magnetic resonance images. Eur Spine J 2015;24(10):2236-43. (PMID:26292958).

19. Yamashita K, Aono $H$, Yamasaki R. Clinical classification of patients with lumbar spinal stenosis based on their leg pain syndrome: its correlation with 2-year surgical outcome. Spine (Phila Pa 1976) 2007;32(9):980-5. (PMID:17450073).

20. Ozcan-Eksi EE, Yagci I, Erkal H, Demir-Deviren S. Paraspinal muscle denervation and balance impairment in lumbar spinal stenosis. Muscle Nerve 2016;53(3):422-30. (PMID:26138076).

21. Bouhassira $D$, Lantéri-Minet $M$, Attal $N$, Laurent B, Touboul C. Prevalence of chronic pain with neuropathic characteristics in the general population. Pain 2008;136:380-7. (PMID:17888574).

22. Park SY, An HS, Moon SH, et al. Neuropathic Pain Components in Patients with Lumbar Spinal Stenosis. Yonsei Med J 2015;56(4):1044-50. (PMID:26069129).

23. Weber C, Giannadakis C, Rao V, et al. Is There an Association Between Radiological Severity of Lumbar Spinal Stenosis and Disability, Pain, or Surgical Outcome?: A Multicenter Observational Study. Spine (Phila Pa 1976) 2016;41(2):E78-83. (PMID:26352747).

24. Sigmundsson FG, Kang $X P$, Jönsson $B$, Strömqvist B. Correlation between disability and MRI findings in lumbar spinal stenosis: a prospective study of 109 patients operated on by decompression. Acta Orthop 2011;82(2):204-10. (PMID:21434811). 